Article available at http://www.parasite-iournal.org or http://dx.doi.org/10.1051/parasite/2002094333

\title{
EOSINOPHIL AND MAST CELL EXPRESSION IN HOST SKIN DURING LARVAL DEVELOPMENT OF THE HUMAN BOT FLY DERMATOBIA HOMINIS
}

\author{
PEREIRA M.C.T.* \& LEITE A.C.R.*
}

\section{Summary :}

Eosinophils and mast cells in the skin of Wistar rats (Rattus norvegicus) infested with Dermatobia hominis larvae were quantified and analysed. Eosinophils in parasitised skin increased markedly until 10 days post-infestation (dpi) and then decreased up to $28 \mathrm{dpi}$, close to the point at which third stage larvae (L3) emerged from the host. In ascending order, the highest numbers of eosinophils were seen in rats at $1,4,28,20,15$ and 10 dpi, corresponding to the first, $(1$ and 4$)$ third $(20$ and 28$)$ and second (10 and 15) instars. Except for 1 dpi, eosinophil numbers were significantly higher than those seen in control animals. Mast cell numbers were highest in early infestations ( $4 \mathrm{dpi}$ ), followed by those at $20 \mathrm{dpi}$. In increasing order, numbers of mast cells were greatest at $10,28,15,1,20$ and $4 \mathrm{dpi}$, although significant differences with control animals were only seen at 10 and $28 \mathrm{dpi}$. Eosinophils and mast cells showed negative correlation only in animals with second instar larvae (10 and 15 dpi). Comparative analyses were also carried out after considering the skin into four distinct regions. The results suggest that the expression of both cell types, particularly eosinophils, is an important host response to infestation by $D$. hominis.

KEY WORDS : eosinophil, mast cell, myiasis, skin, Dermatobia hominis
Résumé : EXPRESSION D'ÉOSINOPHILE ET DE MASTOCYTE DANS DERME SUPERFICIEL DE L'HÔTE DURANT LE DÉVELOPPEMENT LARVAIRE DE DERMATOBIA HOMINIS

Les éosinophiles et les mastocytes du derme superficiel de rats Wistar (Rattus norvegicus), infectés par des larves de Dermatobia hominis, ont été quantifiés et analysés. Les éosinophiles dans la couche superficielle parasitée ont augmenté de manière marquée jusqu'au 10 ème jour aprés l'infection (dpil), puis décru jusqu'au $28^{\text {ème }}$ jour qui correspond au moment où la larve de troisième stage émerge de l'hôte. En ordre croissant, les comptages d'éosinophiles les plus élevés ont été observés chez les rats après $1,4,28,20,15$ et 10 dpi, correspondant au premier (1 et 4), troisième (20 et 28) et deuxième (10 et 15) stages. Les quantités d'éosinophiles ont été significativement plus élévées que celles observées pour les animaux du groupe contrôle là l'exception de $1 \mathrm{dpi})$. Les nombres de mastocytes ont été plus élevés au début de l'infestation (4 dpi), suivis par ceux du 20ème jour. En ordre croissant, les quantités de mastocytes ont été plus élevées pour $10,28,75,1,20$ et 4 dpi, bien que des différences significatives avec le groupe contrôle n'aient été notées que pour 10 et 28 dpi. Les éosinophiles et mastocytes ont montré une corrélation négative seulement chez les animaux ayant une larve du deuxième stage (10 et $15 \mathrm{dpi}$. Des analyses comparatives ont été également effectuées aprés avoir divisé la peau en quatre régions distinctes. Les résultats suggèrent que l'expression des deux types de cellules, particulièrement les éosinophiles, est une réponse importante de l'hôte à l'infestation par D. hominis.

MOTS CLÉS : éosinophile, mastocyte, peau, myiase, Dermatobia hominis.

\section{INTRODUCTION}

Z oonotic cutaneous myiasis caused by the human bot fly Dermatobia hominis is a neotropical disease of medical and veterinary importance. Its major impact is on livestock production (ruminants), causing considerable economic losses (Hall \& Wall, 1995). Although chemical larvicides are used in prophylactic measures against $D$. bominis furinculosis, it remains enzootic in many

\footnotetext{
* Departamento de Parasitologia, Instituto de Ciências Biológicas, Universidade Federal de Minas Gerais, Cx.P.486, 31270-901 Belo Horizonte, MG, Brazil.

Correspondence: A.C.R. Leite.

Tel.: +55-31-34992837 - Fax: +55-31-34992970.

e-mail: rios@mono.icb.ufmg.br
}

countries (Guimarães \& Papavero, 1999b) and development of alternative, more effective tools against $D$. hominis require further studies of the parasite-host relationship (Sandeman, 1996; Otranto, 2001). A previous article (Pereira et al., 2001) reported a suitable laboratory model for studying $D$. hominis myiasis. Large numbers of eosinophils and mast cells were observed in skin lesions infested by Hypoderma lineatum (Villers) (Simmons, 1937; Nelson \& Weintraub, 1972), D. hominis (Oliveira-Sequeira et al., 1996) Lucilia cuprina (Wedemann) (Bowles et al., 1992: Colditz et al., 1994) but little is known about a quantitative measurements of both cells. As a continuation of our earlier studies on D. bominis (Pereira et al., 2001), we monitored the numbers of eosinophils and mast cells present in bots through the whole period of larval development. 
PEREIRA M.C.T. \& LEITE A.C.R.

\section{MATERIALS AND METHODS}

1 wo month-old adult male Wistar rats (Rattus norvegicus) were each submitted to skin infestation with four newly hatched $D$. hominis reared in our laboratory. Six groups each consisting of five infested rats were sacrificed to provide skin samples at $1,4,10,15,20$ and 28 days-post-infestation (dpi) corresponding to different stages of bot development (Pereira et al., 2001); larvae at 1 and 4 dpi corresponded to the first instar (L1), those at 10 and $15 \mathrm{dpi}$ to the second instar (L2) and those at 20 and 28 dpi to the third instar (L3). Five other rats were maintained as a control group. The tissue obtained was fixed in modified Millonig's phosphate-buffered formalin at $\mathrm{pH}$ 7.4 and embedded in paraffin. Histological skin sections $(5 \mu \mathrm{m})$ of each sample were stained with Dominici and both eosinophils and mast cells counted within 40 total fields or 10 fields at a magnification of $400 \mathrm{x}$ in each of four distinct regions that were designated as A (superficial dermis), B (intermediary dermis), C (deep dermis plus superficial subdermis) and D (deep subdermis). Intravascular cells were excluded from the count.

The results were analysed by non-parametric statistic methods (WinSTAT, 1994), using differences in mean ranks, by comparison among all the groups using independent (Kruskal-Wallis test) and dependent (Friedman test) variables and between pairs of the groups using independent (Mann-Whitney U-test) and dependent (Wilcoxon test) variables. Differences between the skin regions of infested animals were not analysed by Mann-Whitney U-test. The data are represented in box and whisker plots, the middle line corresponding to the median and the lower and upper lines representing the 25 th and 75 th percentiles, respectively $(50 \%$ of the data fall within the box, and 25\% each above and below). The whiskers above and below the box plot indicate the 95th and 5th percentiles, respectively. Spearman rank correlation between eosinophils and mast cells was also analysed between the control, L1, L2 and L3 groups. Values of P $\leq 0.05$ were considered significant.

\section{RESULTS}

\section{EOSINOPHILS}

E osinophil numbers counted in the four distinct regions of dermal and subdermal tissue (Figs 1 and 2) of control animals and those infested with $D$. hominis are shown in Table I. When control and infested groups were compared by Kruskal-Wallis test without considering regions separately, eosinophil numbers were significantly different, their mean rank being the following, in ascending order: 0 (control), 1, 4, 28, 20, 15 and 10 dpi (Fig. 3). Based on analysis by Mann-Whitney U-test, the numbers of eosinophils in all infested groups except $1 \mathrm{dpi}$ were significantly different from the control. When each infested group was compared by Mann-Whitney U-test with the next

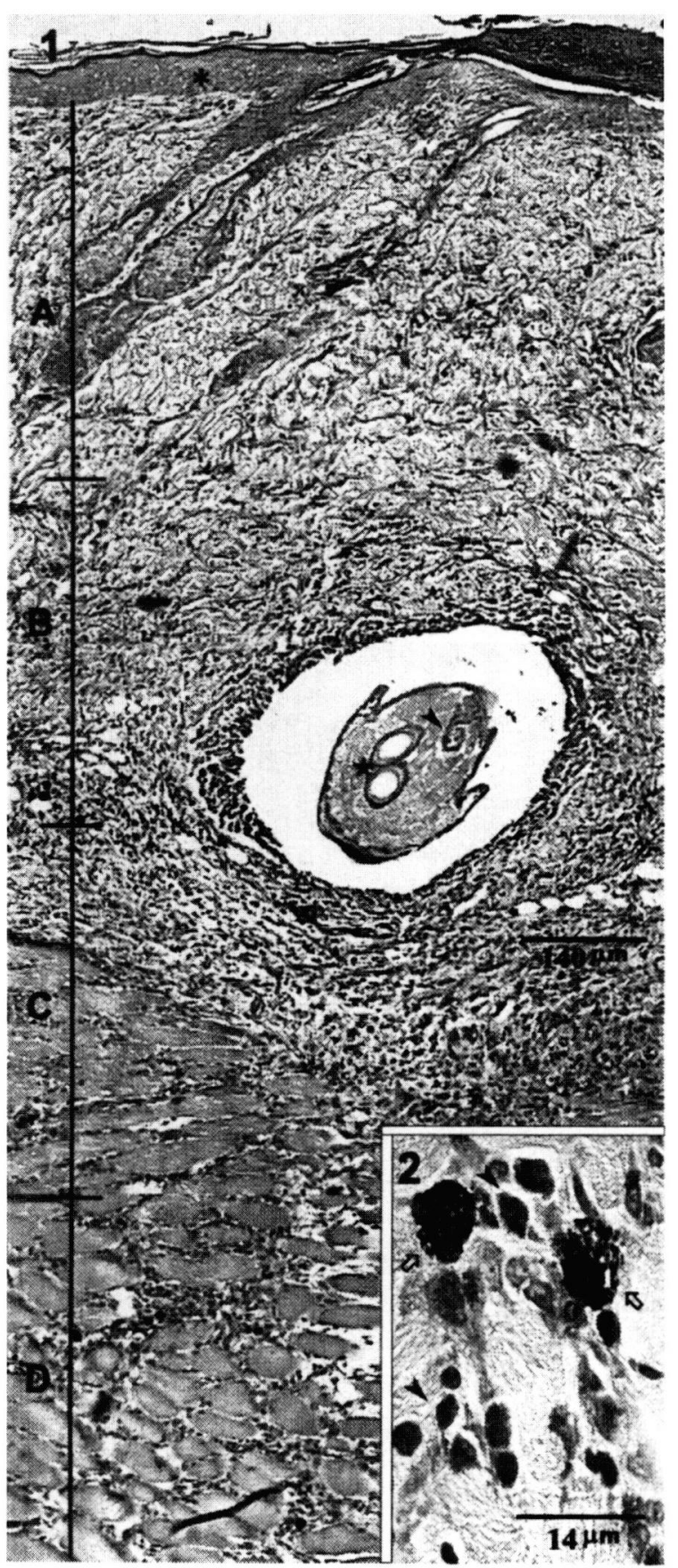

Figs 1, 2. - Skin sections of rat infested with Dermatobia bominis larvae. (1) Typical example at four days post-infestation, indicating the regions (A, B, C and D) where the eosinophils and mast cells were counted. Asterisk = epidermis, star $=$ two larval tracheoles and arrowhead = larval gut. (2) Eosinophils (arrowheads) and mast cells (arrows) at 10 days post-infestation 


\begin{tabular}{|c|c|c|c|c|c|c|c|c|c|c|c|c|c|c|c|c|}
\hline \multirow[b]{2}{*}{ Group } & \multicolumn{4}{|c|}{ A region } & \multicolumn{4}{|c|}{ B region } & \multicolumn{4}{|c|}{$C$ region } & \multicolumn{4}{|c|}{ D region } \\
\hline & $\mathrm{N}$ & M & $\mathrm{X}$ & SD & $\mathrm{N}$ & M & $X$ & SD & $\mathrm{N}$ & M & $\mathrm{X}$ & SD & $\mathrm{N}$ & M & $\mathrm{X}$ & SD \\
\hline Control & 43.0 & 0.4 & 0.9 & 1.1 & 41.0 & 0.6 & 0.8 & 0.8 & 59.0 & 0.5 & 1.2 & 1.5 & 34.0 & 0.3 & 0.7 & 1.0 \\
\hline 1 day & 133.0 & 2.7 & 2.7 & 2.2 & 177.0 & 3.5 & 3.5 & 2.5 & 141.0 & 2.8 & 2.8 & 1.6 & 71.0 & 1.8 & 1.4 & 0.9 \\
\hline 4 days & 118.0 & 2.5 & 2.4 & 1.2 & 242.0 & 3.3 & 4.8 & 4.2 & 318.0 & 6.5 & 6.4 & 3.9 & 162.0 & 3.5 & 3.2 & 2.8 \\
\hline 10 days & $1,019.0$ & 6.3 & 20.3 & 25.7 & $5,511.0$ & 87.0 & 110.2 & 38.0 & $3,745.0$ & 71.6 & 74.9 & 37.8 & $2,323.0$ & 28.7 & 46.5 & 32.7 \\
\hline 15 days & 175.0 & 3 & 3.5 & 1.2 & $1,343.0$ & 13.6 & 26.9 & 24.4 & $2,464.0$ & 52.8 & 49.2 & 25.4 & $1,495.0$ & 23.4 & 29.9 & 28.3 \\
\hline 20 days & 136.0 & 2.5 & 2.7 & 1.2 & 627.0 & 11.6 & 12.5 & 7.2 & $1,183.0$ & 30.3 & 23.7 & 13.9 & 553.0 & 5.9 & 11.1 & 15.3 \\
\hline 28 days & 176.0 & 3.5 & 3.5 & 1.5 & 464.0 & 9.5 & 9.3 & 1.7 & 946.0 & 20.2 & 18.9 & 7.1 & 335.0 & 6.5 & 6.7 & 3.8 \\
\hline
\end{tabular}

Table I. - Total number (N), median (M), mean (X) and stand deviation (SD) of eosinophils counted in the four skin regions of the control and infested rat with Dermatobia hominis larvae.

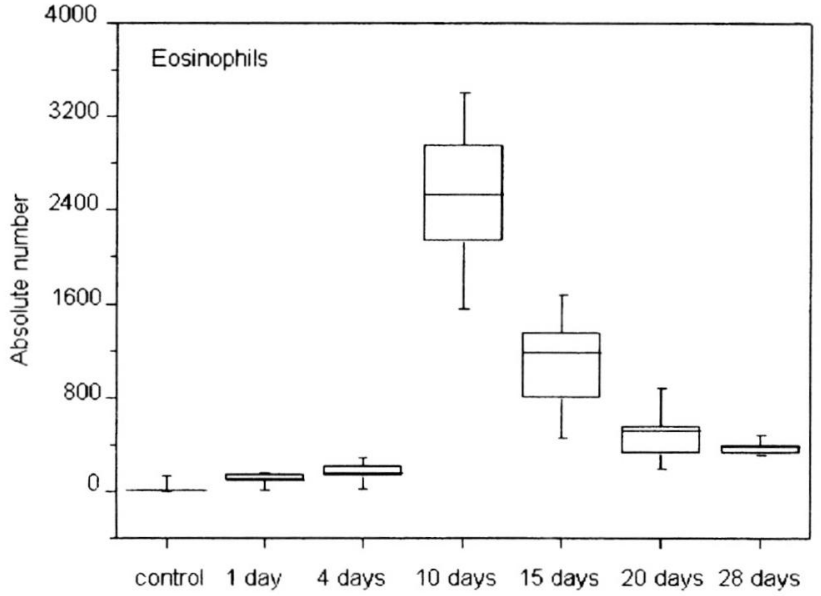

Fig. 3. - Box and whisker plots representing the numbers of eosinophils in the skin of control rats and those infested with Dermatobia hominis larvae for different periods (Kruskal-Wallis test).

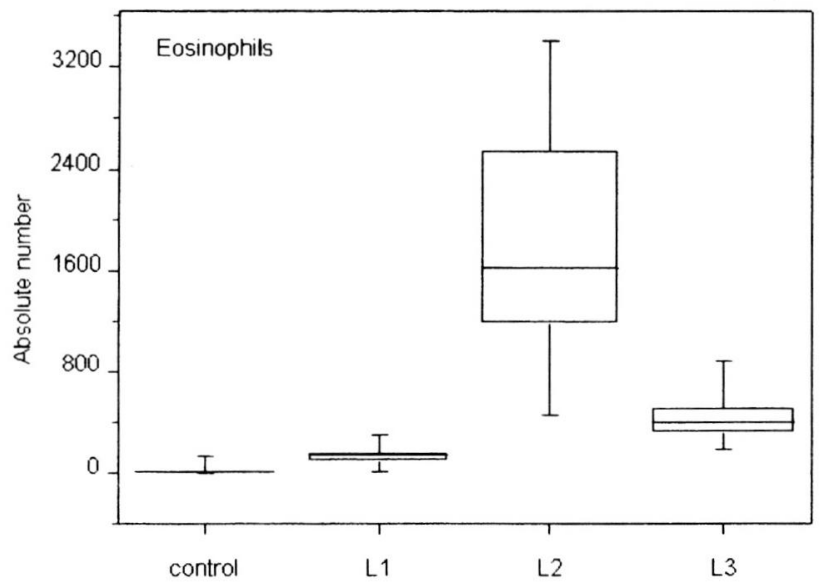

Fig. 4. - Box and whisker plots representing the numbers of eosinophils in the skin of control rats and those infested with Dermatobia bominis based on larval development stage (Kruskal-Wallis test).

in rank, significant differences were seen for all pairs except 1 vs 4 and 20 vs 28 dpi. Comparisons between each of the three larval instars in the host and control animals revealed significant differences (Kruskal-Wallis, $\mathrm{P}<0.05$ ), numbers of eosinophils being successively greater in L1, L3 and L2 (Fig. 4). When analysed by Mann-Whitney U test, significant differences were observed for L2 (L1 vs L2 and L2 vs L3) and L3 (L1 vs L3). Considering each of the four regions of the section separately, eosinophils (Kruskal-Wallis, $\mathrm{P}<0.05$ ) were detected in $\mathrm{B}$ and $\mathrm{C}$ at the following number of days post-infestation (ranked from lowest to highest numbers): 0 (control), 1, 4, 28, 20, 15 and 10. In D eosinophils were successively most abundant on 0 (control), 1, 4, 20, 28, 15 and 10 dpi. They were indistinct in A. Comparison between similar regions in rats of the control and infested groups did not reveal statistically significant differences only between $1 \mathrm{dpi} v s$ control (for all regions) and 4 or $20 \mathrm{dpi} v s$ control for both $\mathrm{A}$ and $\mathrm{D}$. When each of the three larval stages was compared with the control, significantly higher eosinophil numbers $(\mathrm{P}<0.05)$ occurred in regions $\mathrm{A}$, $\mathrm{B}, \mathrm{C}$ and $\mathrm{D}$ (mean rank: L1, L3 and L2). Mean rank values of numbers of eosinophils in skin regions associated with larval stages are illustrated in Figure 5. Absence of significant differences in eosinophil numbers were observed only between the control group and that infested with L1 larvae in the A, C and D regions. Significant differences in eosinophil numbers based on the Friedman test (excluding the control group) were observed among the four skin regions,

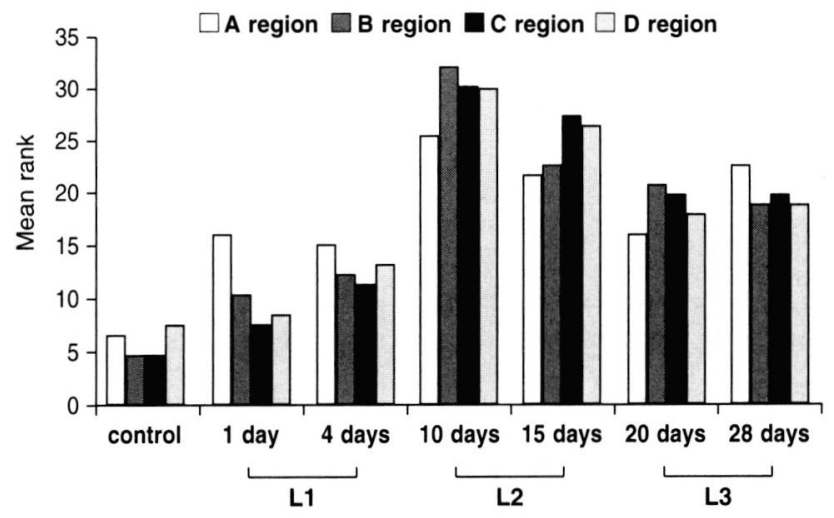

Fig. 5. - Histogram representing mean rank values of eosinophils in the skin of control rats and those infested with Dermatobia hominis larvae, indicating the different regions or sections and three larval stages (L1, L2, L3). 
eosinophil numbers in being highest in region $\mathrm{C}$, followed by B, D and A. Wilcoxon analysis of these findings revealed statistically significant differences in $\mathrm{C}$ vs. each of the other three skin regions, B (B vs A and $\mathrm{B}$ vs $\mathrm{D})$ and $\mathrm{D}(\mathrm{D}$ vs $\mathrm{A}$ ).

\section{MAST CELLS}

The numbers of mast cells in the skin regions (Fig. 2) are presented in Table II. When results from all regions were analysed together by Kruskal-Wallis test, the order of mean ranks was: 10, 28, 0 (control), 15, 1, 20 and 4 dpi (Fig. 6). Based on analyses by Mann-Whitney $\mathrm{U}$ test, mast cell numbers in the control group were significantly higher than those of infested animals at 10 and 28 dpi. Significant differences were also seen for $1,4,15$ and $20 \mathrm{dpi}$ vs $10 \mathrm{dpi}$, and for 1,4 and 20 dpi vs 28 dpi. Comparisons by Kruskal-Wallis test between mast cell numbers in the controls and those in the three larval stages grouped together were not significant (Fig. 7). By Mann-Whitney U test control vs larval stages or between larval stages mast cell numbers were not significant. Mast cell numbers in skin regions of infested animals (analysed by Kruskal-

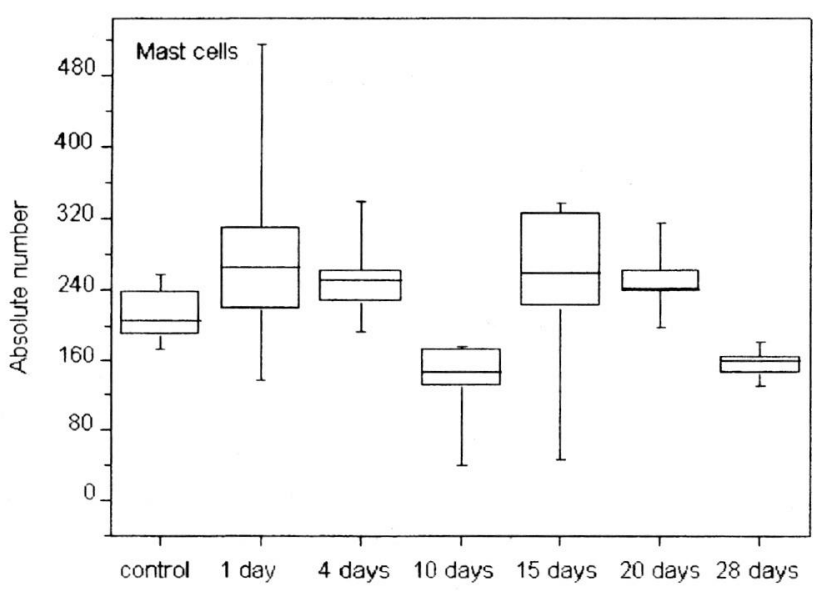

Fig. 6. - Box and whisker plots representing the numbers of mast cells in the skin of control rats and those infested with Dermatobia hominis larvae for different periods (Kruskal-Wallis test).

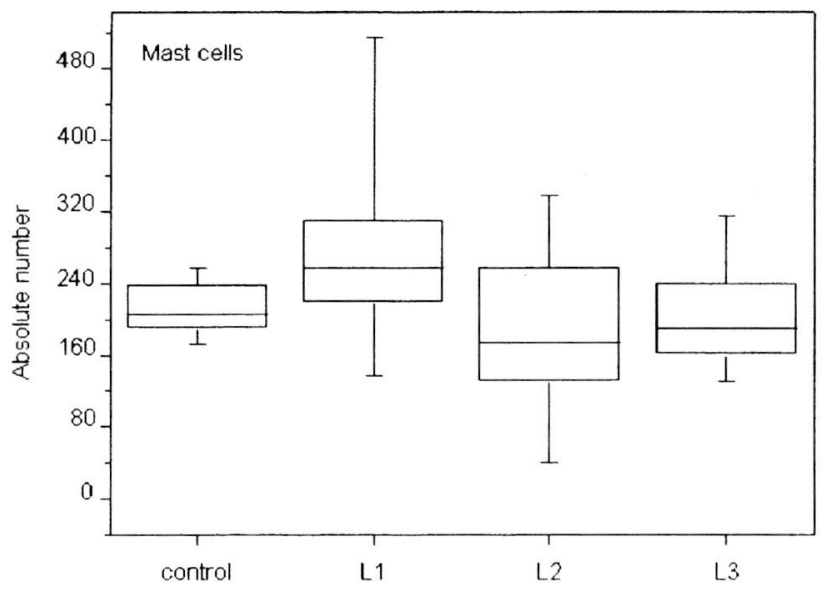

Fig. 7. - Box and whisker plots representing mast cells in the skin of control rats and those infested with Dermatobia hominis based on larval development (Kruskal-Wallis test).

Wallis) were significantly different from than those of the corresponding control in A (mean rank: 28, 10, 0 (control), 15, 20, 1, and 4 dpi), B (28, 10, 15, 0 (control), 20, 4, and 1) and $\mathrm{C}(10,28,20,4,15,0$ (control), and $1 \mathrm{dpi}$ ), but not in D. In A and B mast cell numbers were significantly higher than the control at 4 and 1 dpi respectively, whereas in $\mathrm{C}$ they were significantly lower than the control at 10 and $28 \mathrm{dpi}$ ). Comparison of mast cell numbers associated with each of the larval instars by Kruskal-Wallis revealed significant differences only in regions A (ranks according to increasing numbers: control, L2, L3, L1) and B (ranks: L2, L3, control, L1). The mean ranks of mast cells in the four skin regions of control and infested animals are presented in Figure 8. The Mann-Whitney U test revealed significantly higher numbers of mast cells in region $\mathrm{A}$ of skin infested with L1 larvae compared with the control as well as in skin of control rats compared to that of those infested with L3 larvae in region C. Significantly higher numbers of mast cells were seen in skin of infested animals in three regions (ranked in increasing order: D, B, A and C) based on the Friedman test. No significant differences were observed between regions $\mathrm{A}$ and $\mathrm{B}$, but mast cell numbers in

\begin{tabular}{|c|c|c|c|c|c|c|c|c|c|c|c|c|c|c|c|c|}
\hline \multirow[b]{2}{*}{ Group } & \multicolumn{4}{|c|}{ A region } & \multicolumn{4}{|c|}{ B region } & \multicolumn{4}{|c|}{ C region } & \multicolumn{4}{|c|}{ D region } \\
\hline & $\mathrm{N}$ & M & $\mathrm{X}$ & SD & $\mathrm{N}$ & M & $X$ & SD & $\mathrm{N}$ & M & $\mathrm{X}$ & SD & $\mathrm{N}$ & M & $\mathrm{X}$ & SD \\
\hline Control & 230.0 & 4.9 & 4.6 & 0.8 & 225.0 & 4.4 & 4.5 & 1.6 & 417.0 & 8.8 & 8.3 & 2.1 & 161.0 & 3.2 & 3.2 & 1.1 \\
\hline 1 day & 420.0 & 7.4 & 8.4 & 4.3 & 394.0 & 7.8 & 7.9 & 2.4 & 552.0 & 11.0 & 11.0 & 5.0 & 201.0 & 4.4 & 4.0 & 2.0 \\
\hline 4 days & 401.0 & 7.6 & 8.0 & 2.0 & 282.0 & 5.5 & 5.6 & 1.6 & 420.0 & 8.1 & 8.4 & 4.1 & 168.0 & 3.6 & 3.4 & 1.8 \\
\hline 10 days & 178.0 & 3.3 & 3.6 & 2.1 & 215.0 & 4.4 & 4.3 & 2.8 & 163.0 & 3.5 & 3.3 & 2.2 & 108.0 & 2.3 & 2.2 & 1.0 \\
\hline 15 days & 300.0 & 6.3 & 6.0 & 3.8 & 218.0 & 3.5 & 4.4 & 3.1 & 409.0 & 8.8 & 8.2 & 4.6 & 263.0 & 5.3 & 5.3 & 2.5 \\
\hline 20 days & 342.0 & 7.6 & 6.8 & 1.9 & 353.0 & 5.1 & 7.1 & 5.4 & 328.0 & 7.1 & 6.6 & 1.7 & 230.0 & 3.9 & 4.6 & 1.8 \\
\hline 28 days & 187.0 & 3.1 & 3.7 & 1.2 & 158.0 & 3.1 & 3.2 & 0.2 & 251.0 & 4.6 & 5.0 & 0.9 & 184.0 & 3.4 & 3.7 & 1.2 \\
\hline
\end{tabular}

Table II. - Total number (N), median (M), mean (X) and stand deviation (SD) of mast cells counted in the four skin regions of the control and infested rat with Dermatobia bominis larvae. 


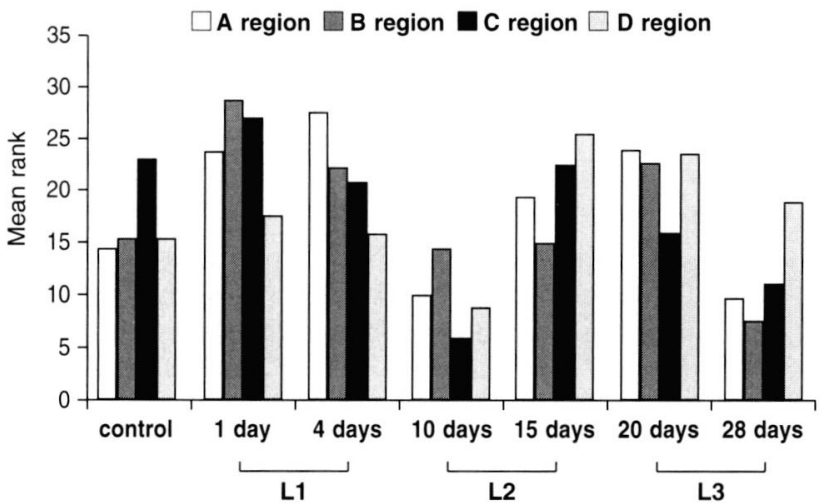

Fig. 8. - Histogram representing mean rank values of mast cells in skin of control rats and those infested with Dermatobia bominis larvae, indicating the regions and three larval stages (L1, L2, L3).

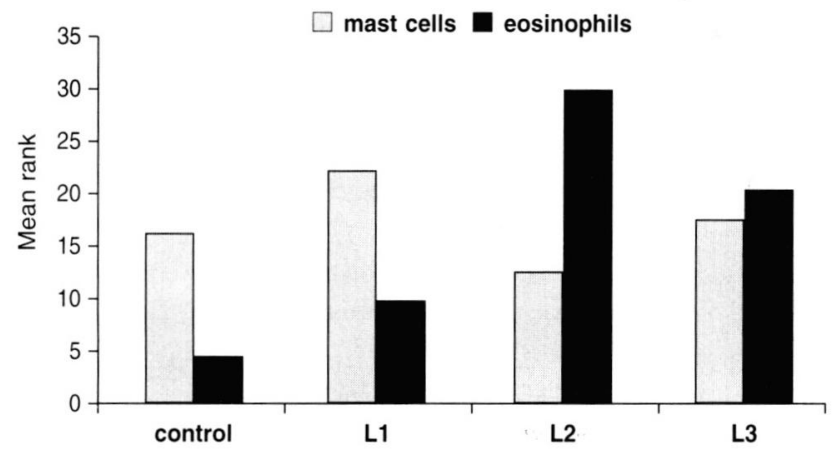

Fig. 9. - Relation between eosinophil and mast cell numbers in control rats and those infested with Dermatobia hominis larvae at different developmental stages.

region $\mathrm{C}$ were significantly higher than those in both $\mathrm{A}$ and $\mathrm{B}$. Cell numbers in $\mathrm{A}$ and $\mathrm{B}$ were also significantly higher than in region $\mathrm{D}$. The association of eosinophils and mast cells (Spearman correlation) showed a significant negative correlation $(r=-0.65, \mathrm{P}=0.02)$ only in animals infested with L2 larvae (Fig. 9).

\section{DISCUSSION}

$\mathrm{H}$ uman bot fly myiasis usually occurs over a period of four-eight weeks, both under natural conditions and in experimental infections involving multiple mammalian hosts (Dunn, 1930; Jobsen \& Mourier, 1972). Other obligatory cutaneous myiases in mammals last only one-two weeks, as in the screwworm fly Cochliomyia hominivorax (Guimarães \& Papavero, 1999a), or several months, as in the warble flies Hypoderma spp. (Scholl, 1993). Immune reactions occur as a response to the physical presence of larvae and to their secretions and excretions, although little is known about the mechanisms involved (Otranto, 2001). Two larval mòlts occur during the parasitic phase of the D. hominis life cycle (L1 to $\mathrm{L} 2$ at about $7 \mathrm{dpi}$ and $\mathrm{L} 2$ to $\mathrm{L} 3$ at about $18 \mathrm{dpi}$ ), after which the mature larva abandons the host, the exit point being marked by a scar which forms within two weeks (Pereira et al., 2001). Although eosinophils and mast cells have been previously noted in dermal myiasis caused by calliphorids and bot flies (Otranto, 2001), the present study represents the first attempt to quantify their presence. Particularly in skin lesions by $D$. hominis, the increase of eosinophils and mast cells has been observed in human case (Grogan et al., 1987) and during the first days in experimental cattle (Oliveira-Sequeira et al., 1996). Significant numbers of eosinophils and mast cells were also observed in small ruminants with naso-sinusal myiasis caused by Oestrus ovis, over $85 \%$ of the infestation being due to L1 larvae (Van-Khanh et al., 1996; 1999). Unlike in the present study based on non-parametric analyses, these authors found that numbers of eosinophils and mast cells were normally distributed in the naso-sinusal tissues of sheep and goats (eosinophils 16-35 times in sheep and eight times in goats; mast cells one-two times in both hosts).

In skin lesions caused by $D$. hominis or other myiasis, eosinophils and mast cells may have functions analogous to those occurring in mammal hosts as a consequence of inflammatory and immune (innate and adaptive) responses against other pathogens (Metcalfe et al., 1997; Behm \& Ovington, 2000). Although their full complement of roles is unknown, the primary function of the eosinophils has been described as mediation in allergic (Fan et al., 2000) and infectious processes (Wikel, 1996; Cara et al., 2000) involving lytic action by secreted products or phagocytosis of cells, tissues and pathogens, including helminths and other metazoan parasites (Maizels \& Holland, 1998; Meeusen \& Balic, 2000). The eosinophilic response to D. hominis infestation was most marked at $10 \mathrm{dpi}$ and was significant during all stages of infestation, whether or not the four skin regions were analysed separately. This occurred during early development of the second instar, whose molecules may be important in eliciting eosinophil chemotaxis in skin. L1 and L3 larvae were also able to elicit eosinophilia, although to a lesser extent. Rapid (four-five days) eosinophil turnover at inflammatory sites (Behm \& Ovington, 2000) also may occur in $D$. hominis infestation.

Eosinophilia in intermediary and deep (but not superficial) dermal and subdermal regions situated close to the bots was probably a response to chemiotatic products produced by the salivary glands and midgut, and secreted through the larval oral opening.

Mast cells, which differentiate and mature in the connective and mucosal tissues of the host, show phenotypic, histochemical and functional heterogeneities 
and are able to exercise phagocytosis, process antigens, produce chemokines, deliver proteases, and express molecular receptors to specific and unspecific stimuli (Metcalfe et al., 1997; Maizels \& Holland, 1998; Holgate et al., 2000). In contrast to the eosinophilia observed in the present study, dermal mastocytosis did not occur during infestation with $D$. hominis, the numbers of mast cells being significantly higher in animals of the control group than those of infested animals at 10 and 28 dpi. Generalised mastocytosis was not observed in skin infested by any of the three larval stages. However, mast cell numbers were significantly higher than controls and were sometimes observed in focal mastocytosis (e.g. in superficial dermis at $4 \mathrm{dpi}$ and intermediary dermis at $1 \mathrm{dpi}$ ). These concentrations probably occurred as a defensive strategy against larval $D$. hominis. In certain areas, including rodent skin, mast cells can deliver specific proteases (Beil et al., 2000). They may not be required in great numbers because they are resident in tissues and have a life span of several months (Yong, 1997). The inverse relationship between cell numbers of the two types in skin parasitised by L2 larvae confirms the crucial importance of eosinophils and mast cell expression in myiasis due to D. hominis. This relationship is the result of complex, flexible mechanisms which should be further studied to help reduce the consequences of dermatobiosis to human and animal health.

\section{ACKNOWLEDGEMENTS}

$\mathrm{T}$ his work was partially supported by grants from CNPq, Brazil. We are grateful to Dr. Paul Williams for revision of the original manuscript.

\section{REFERENCES}

Behm C.A. \& Ovington K.S. The role of eosinophils in parasitic helminth infections: insights from genetically modified mice. Parasitology Today, 2000, 16, 202-209.

Beil W.J., Schulz M. \& Wefelmeyer U. Mast cell granule composition and tissue location - a close correlation. Histology and Histopathology, 2000, 15, 937-946.

Bowles V.M. Cellular immune responses in the skin of sheep infected with larvae of Lucilia cuprina, the sheep blowfly. Veterinary Parasitology, 1992, 44, 151-162.

Cara D.C., Negrão-Correa D. \& Teixeira M.M. Mechanisms underlying eosinophil trafficking and their relevance in vivo. Histolology and Histopathology, 2000, 15, 899-920.

Colditz I.G., Lax J., Mortimer S.I., Clarke R.A. \& Beh K.J. Cellular inflammatory responses in skin of sheep selected for resistance of susceptibility to fleece rot and fly strike. Parasite immunology, 1994, 16, 289-296.
DunN L.H. Rearing the larvae of Dermatobia bominis Linn. in man. Psyche, 1930, 37, 327-342.

Fan G.K., Itoh T., Imanaka M., Fujieda S. \& Takenaka H. Eosinophilic apoptosis in sinus mucosa relationship to tissue eosinophilia and its resolution in allegic sinusitis. Journal of Allergy and Clinical Immunology, 2000, 106, 551-558.

Grogan T.M., Payne C.M., Payne T.B., Spier C., Cromey D.W., RANGEl C. \& Richter L. Cutaneous myiasis immunohistologic and ultrastructural morphometric features of human botfly lesion. American Journal of Dermatopathology, 1987, 9, 232-239.

Guimaràes J.H. \& Papavero N. Myiasis caused by obligatory parasites. II. Cochliomyia Townsend (Calliphoridae). In: Myiasis in Man and Animals in the Neotropical Region, Bibliographic Database. Guimarães J.H. \& Papavero N. (eds), Plêiade/FAPESP, 1999a, 97-164.

Guimaràes J.H. \& Papavero N. Myiasis caused by obligatory parasites. VI. Dermatobia bominis (Linnaeus Jr) (Cuterebridae). In: Myiasis in Man and Animals in the Neotropical Region, Bibliographic Database. Guimarães J.H. \& Papavero N. (eds), Plêiade/FAPESP, 1999b, 257-334.

Hall M. \& Wall R. Myiasis of human and domestic animals. Advances in Parasitology, 1995, 35, 257-334.

Holgate S.T., Donna E.D., Lackie P.M., Wilson S.J., PuddiCOMBE S.M. \& LORDAN J.L. Epithelial-mesenchymal interactions in the pathogenesis of asthma. Journal of Allergy and Clinical Immunology, 2000, 105, 193-204.

JOBSEn J.A. \& MOURIER H. The morphology of the larval instars and pupa of Dermatobia hominis L. Jr (Diptera: Cuterebridae). Entomologische Berichten, 1972, 32, 218-224.

Maizels R.M. \& Holland M.J. Parasite immunity: pathways for expelling intestinal helminths. Current Biology, 1998, 8, R711-R714.

Meeusen E.N.T. \& Balic A. Do eosinophils have a role in the killing of helminth parasites? Parasitology Today, 2000, 16, 95-101.

Metcalfe D.D., Baram D. \& Mekori Y.A. Mast cells. Physiological Reviews, 1997, 77, 1033-1079.

Nelson W.A. \& Weintraub J. Hypoderma lineatum (De Vill.) (Diptera: Oestridae): invasion of the bovine skin by newly hatched larvae. Journal of Parasitology, 1972, 58, 614-624.

Oliveira-Sequeira T.C.G., Sequeira J.L., Schmitt. F.L. \& Lello E. Histological and immunological reaction of cattle skin to first-instar larvae of Dermatobia hominis. Medical and Veterinary Entomology, 1996, 10, 323-330.

OTRANTO D. The immunology of myiasis: parasite survival and host defense strategies. Trends in Parasitology, 2001, 17, 176-182.

Pereira M.C.T., Leite V.H.R. \& Leite A.C.R. Experimental skin lesions from larvae of the bot fly Dermatobia hominis. Medical and Veterinary Entomology, 2001, 15, 22-27.

SANDEMAN R.M. Immune responses to mosquitoes and flies. In: The Immunology of Host-Ectoparasitic Arthropod Relationships. Wiker S.K (ed), CAB International, Wallingford, 1996, 175-203.

Simmons S.W. Some histopathological changes caused by Hypoderma larvae in the esophagus of cattle. Journal of Parasitology, 1937, 23, 376-381. 
Scholl P.J. Biology and control of cattle grubs. Annual Review of Entomology, 1993, 39, 53-70.

Van-Khanh N., Bourges N., Concordet D. \& Dorchies P. Mastocytes et éosinophiles de la muqueuse respiratoire du mouton infesté par Oestrus ovis (Linné, 1761). Parasite, 1996, 3, 217-221.

Van-Khanh N., Jacquiet P., Duranton C., Bergeaud J.P., Prevot F. \& Dorchies P. Réaction cellulaires des muqueuses nasales et sinusales des chèvre et des moutons à l'infestation naturelle par Oestrus ovis Linné 1758 (Diptera: Oestridae). Parasite, 1999, 2, 141-149.

WIKEL S.K. Immunology of the skin. In: The Immunology of Host-Ectoparasitic Arthropod Relationships. Wikel S.K. (ed), CAB International, Wallingford, 1996, 1-29.

Winstat. The statistics program for windows. Reference Manual, Version 3.0, 3rd edn, Kalmia Company, Cambridge, 1994, 1-257.

YONG L.C.J. The mast cell: origin, morphology, distribution, and function. Experimental and Toxicologic Pathology, 1997, 49, 409-424.

Reçu le 24 avril 2002 Accepté le 27 août 2002 